\title{
Familial Protein S Deficiency Is Associated with Recurrent Thrombosis
}

\author{
Philip C. Comp, Randal R. Nixon, M. Robert Cooper, \\ and Charles T. Esmon \\ Section of Hematology, Department of Medicine, and Department \\ of Biochemistry, University of Oklahoma Health Sciences Center \\ at Oklahoma City, Oklahoma; Department of Medicine, Wake \\ Forest University Medical Center, Bowman Gray School of \\ Medicine, Winston-Salem, North Carolina; Thrombosis/ \\ Hematology Research Program, Oklahoma Medical Research \\ Foundation, Oklahoma City, Oklahoma 73126
}

bstract. Recent studies have demonstrated that protein $\mathrm{C}$ deficiency is associated with recurrent familial thrombosis. In plasma, activated protein $\mathrm{C}$ functions as an anticoagulant. This anticoagulant response requires a vitamin $\mathrm{K}$-dependent plasma protein cofactor, referred to as protein $\mathrm{S}$. Since the anticoagulant activity of activated protein $C$ is dependent on protein $\mathrm{S}$, we hypothesized that patients lacking functional protein $\mathbf{S}$ might have associated thrombotic disease. Two related individuals with otherwise normal coagulation tests are described whose plasma is not effectively anticoagulated with activated protein C. Addition of purified human protein $S$ to their plasma restores a normal anticoagulant response to activated protein $\mathrm{C}$. We have developed a rapid one-stage clotting assay for protein $S$ to quantitate the level of protein $S$ in their plasma. Plasma is depleted of protein $\mathbf{S}$ by immunoadsorption with immobilized antiprotein $S$ antibodies. The resultant plasma responds poorly to activated protein $C$, but is effectively anticoagulated in a dose-dependent fashion upon addition of purified protein $S$ or small quantities of plasma. The affected individuals possess $<5 \%$ protein $\mathrm{S}$ activity. Using Laurell rockets, protein $\mathrm{S}$ antigen was detected in the plasma but was at reduced levels of 13 and $18 \%$ in the two individuals. When the barium eluate of the patient plasma was chromatographed on quaternary aminoethyl Sephadex, a single

Send reprint requests to Dr. Comp, Oklahoma Memorial Hospital, Oklahoma City, OK 73126.

Received for publication 21 February 1984 and in revised form 2 July 1984.

J. Clin. Invest.

(c) The American Society for Clinical Investigation, Inc.

0021-9738/84/12/2082/07 $\$ 1.00$

Volume 74, December 1984, 2082-2088 peak of protein $S$ antigen devoid of protein $S$ anticoagulant cofactor activity was detected early in the chromatogram. In contrast, the barium eluate from normal donors separated into two peaks, one emerging early and also devoid of anticoagulant cofactor, and the second peak with anticoagulant activity emerging later. The first peak of protein $S$ antigen, from both the normal donor and the patient, chromatographed in the region of the complement component C4-binding protein-protein $\mathrm{S}$ complex. These studies suggest that protein $\mathrm{S}$ deficiency may result in recurrent thrombotic disease.

\section{Introduction}

Protein S is a vitamin $\mathrm{K}$-dependent plasma protein that was discovered in 1977 (1). At that time, no function was ascribed to protein S. Recently, a role for protein $S$ in the expression of activated protein $C$ anticoagulant activity has been proposed (2). Activated protein $C$ inhibits the blood clotting cascade at the levels of Factor V and Factor VIII. In normal plasma, as little as $0.1 \mu \mathrm{g} / \mathrm{ml}$ activated protein $C$ results in significant prolongation of the plasma clotting time. In 1980, Walker observed that protein S-deficient plasma was no longer effectively anticoagulated by activated protein $C(2)$. Subsequent studies revealed that protein $S$ serves as a cofactor for activated protein C $(3,4)$. Protein $S$ forms a 1:1 complex with activated protein $C$ on the surface of membranes (3). This complex inactivates Factor $\mathrm{Va}$ more rapidly than free activated protein $\mathrm{C}$.

These in vitro studies suggest that protein $S$ may be essential for expression of the anticoagulant effects of activated protein $\mathrm{C}$ in vivo. Clinical studies have demonstrated that patients who are congenitally protein $\mathrm{C}$-deficient are predisposed to recurrent thrombosis $(5,6)$, presumably on the basis of abnormal regulation of intravascular clotting. Since protein $S$ is required for optimal expression of activated protein $\mathbf{C}$ anticoagulant activity, we hypothesized that a protein $\mathrm{S}$ deficiency could predispose individuals to thrombotic disease. We 
now describe two brothers with recurrent thrombosis who lack functional protein $\mathrm{S}$.

\section{Methods}

Reagents. Reagents were purchased from sources previously recorded (7), and were of the highest grade commercially available.

Protein purification. Human plasma was the generous gift of the Oklahoma Blood Institute. Human vitamin K-dependent factors were purified from plasma in the following manner. Frozen plasma was thawed and made $10 \mathrm{mM}$ in benzamidine $\mathrm{HCl}$ and then diluted $1: 1$ into $20 \mathrm{mM}$ Tris $\mathrm{HCl}, \mathrm{pH}$ 7.5. The vitamin $\mathrm{K}$-dependent proteins from 30 liters of starting plasma were adsorbed onto $30 \mathrm{~g}$ of quaternary aminoethyl (QAE) Sephadex Q50, previously equilibrated in $0.1 \mathrm{M}$ $\mathrm{NaCl}, 0.02 \mathrm{M}$ Tris- $\mathrm{HCl}, \mathrm{pH} 7.5$, by gentle stirring for $1 \mathrm{~h}$ at $22^{\circ} \mathrm{C}$. Stirring was ceased, and the QAE Sephadex was allowed to settle for $30 \mathrm{~min}$. The plasma was siphoned off, and the QAE Sephadex was packed into a $10 \times 60 \mathrm{~cm}$ column, and washed with 1 liter of $0.15 \mathrm{M}$ $\mathrm{NaCl}, 0.02 \mathrm{M}$ Tris- $\mathrm{HCl}, 5 \mathrm{mM}$ benzamidine $\mathrm{HCl}, \mathrm{pH} 7.5$, before the vitamin K-dependent proteins were eluted with 2 liters of $0.4 \mathrm{M} \mathrm{NaCl}$, $0.02 \mathrm{M}$ Tris- $\mathrm{HCl}, 5 \mathrm{mM}$ benzamidine $\mathrm{HCl}, \mathrm{pH}$ 7.5. All of these steps were at $22^{\circ} \mathrm{C}$. The eluate containing the vitamin $\mathrm{K}$-dependent factors was pooled and diluted 1:2.7 in $0.01 \mathrm{M} \mathrm{Na}$ oxalate, $5 \mathrm{mM}$ benzamidine $\mathrm{HCl}, 0.02 \mathrm{M}$ Tris $\mathrm{HCl}, \mathrm{pH}$ 7.5. The eluate was adsorbed onto $500 \mathrm{~g}$ of $\mathrm{BaSO}_{4}$ by gentle mixing for $1 \mathrm{~h}$, and the $\mathrm{BaSO}_{4}$ was harvested by centrifugation at $2,500 \mathrm{~g}$ for $5 \mathrm{~min}$ at $4^{\circ} \mathrm{C}$. The pellet was resuspended in 2 liters of $0.078 \mathrm{M} \mathrm{NaCl}, 1 \mathrm{mM} \mathrm{Na}$ citrate, $10 \mathrm{mM}$ Tris $\mathrm{HCl}, 1$ $\mathrm{mM}$ benzamidine $\mathrm{HCl}, \mathrm{pH}$ 7.5. The $\mathrm{BaSO}_{4}$ was harvested by centrifugation as described above. The vitamin $\mathrm{K}$-dependent factors were eluted from the $\mathrm{BaSO}_{4}$ by suspension in 2 liters of $0.1 \mathrm{M} \mathrm{Na}$ citrate, $\mathrm{pH}$ 5.8. The $\mathrm{BaSO}_{4}$ was harvested by centrifugation as described above, and eluted a second time with 2 liters of the citrate buffer. The two eluates were pooled.

The pooled eluates were diluted 1:3.3 into $0.02 \mathrm{M}$ Tris $\mathrm{HCl}, 5$ $\mathrm{mM}$ benzamidine $\mathrm{HCl}$, $\mathrm{pH} 7.5$, and the vitamin $\mathrm{K}$-dependent factors were adsorbed onto QAE Sephadex Q50 (150 ml settled volume), and equilibrated in $0.18 \mathrm{M} \mathrm{NaCl}, 5 \mathrm{mM} 2$-( $N$-morpholino)ethanesulfonic acid (MES)', $5 \mathrm{mM}$ benzamidine $\mathrm{HCl}, \mathrm{pH} 6.0$, for $1 \mathrm{~h}$ at $22^{\circ} \mathrm{C}$. The QAE Sephadex was allowed to settle for $30 \mathrm{~min}$, the supernatant was removed by siphoning, and the QAE Sephadex was collected in a Buchner funnel overlayed with nylon cloth, and washed with $200 \mathrm{ml}$ of $0.18 \mathrm{M} \mathrm{NaCl}, 5 \mathrm{mM}$ MES, $5 \mathrm{mM}$ benzamidine $\mathrm{HCl}, \mathrm{pH}$ 6.0. A thick slurry of this QAE Sephadex was then packed on top of a prepacked $2.5 \times 90 \mathrm{~cm}$ column of QAE Sephadex Q50 equilibrated in this same buffer to give a total column height of $120 \mathrm{~cm}$. From melting the plasma to this step requires $10 \mathrm{~h}$. The column was developed at $4^{\circ} \mathrm{C}$ with a linear gradient ( 1 liter/reservoir) from 0.18 to $0.5 \mathrm{M} \mathrm{NaCl}$ in $5 \mathrm{mM}$ MES, $5 \mathrm{mM}$ benzamidine $\mathrm{HCl}, \mathrm{pH}$ 6.0. The column requires $\sim 30 \mathrm{~h}$ to develop. Protein $\mathrm{C}$ and protein $\mathrm{S}$ emerged in front of the prothrombin peak, and were almost completely resolved from prothrombin. The protein $\mathrm{S}$ emerged slightly ahead of the protein $\mathrm{C}$, and the two proteins were only partially resolved.

Protein $\mathrm{S}$ was further purified by a modification of the method of Dahlback and Stenflo (8). Routinely, the protein S peak was identified by the functional protein $\mathrm{S}$ assay described below. Protein $\mathrm{C}$ was

1. Abbreviations used in this paper: $\mathrm{C} 4 \mathrm{bp}$, complement component C4-binding protein; MES, 2-( $N$-morpholino)ethanesulfonic acid; QAE, quaternary aminoethyl. removed from the protein $\mathrm{S}$ by adsorption on a murine monoclonal IgG antibody to human protein $C$ coupled to Affigel 10 (Bio-Rad Laboratories, Richmond, $\mathrm{CA}$ ). The protein $\mathrm{S}$ peak was partially purified by $\left(\mathrm{NH}_{4}\right)_{2} \mathrm{SO}_{4}$ fractionation. Solid $\left(\mathrm{NH}_{4}\right)_{2} \mathrm{SO}_{4}$ was added at $4^{\circ} \mathrm{C}$ to bring the sample to $25 \%$ saturation, and stirred for $30 \mathrm{~min}$. The precipitate was removed by centrifugation at $15,000 \mathrm{~g}$ for $30 \mathrm{~min}$ at $4^{\circ} \mathrm{C}$. The supernatant containing the protein $S$ was brought to $70 \%$ saturation by adding $\left(\mathrm{NH}_{4}\right)_{2} \mathrm{SO}_{4}$, and stirred for $30 \mathrm{~min}$. The pellet was collected by centrifugation as described above. The pellet was resuspended in $5-10 \mathrm{ml}$ of $50 \mathrm{mM}$ Tris $\mathrm{HCl}, \mathrm{pH} 7.5$, and $2 \mathrm{mM}$ diisopropyl fluorophosphate. The precipitate $(10 \mathrm{ml}, 5 \mathrm{mg} / \mathrm{ml})$ was dialyzed against $0.05 \mathrm{M} \mathrm{NaCl}, 1 \mathrm{mM}$ EDTA, $1 \mathrm{mM}$ benzamidine $\mathrm{HCl}$, $0.02 \% \mathrm{Na}$ azide, $50 \mathrm{mM}$ Tris $\mathrm{HCl}, \mathrm{pH} 7.5$, and chromatographed on a blue Sepharose column $(1.5 \times 52 \mathrm{~cm})$ at $22^{\circ} \mathrm{C}$. The column was developed with a linear gradient from $0.05 \mathrm{M} \mathrm{NaCl}$ to $0.2 \mathrm{M} \mathrm{NaCl}$ ( $150 \mathrm{ml} /$ reservoir) in $1 \mathrm{mM}$ EDTA, $1 \mathrm{mM}$ benzamidine, $50 \mathrm{mM}$ Tris $\mathrm{HCl}, \mathrm{pH}$ 7.5. Protein $\mathrm{S}$ activity was detected in the first protein peak to emerge from the column. Most of the trace contaminants were separated from the protein $\mathrm{S}$ by chromatography at $22^{\circ} \mathrm{C}$ on a column $(0.6 \times 25 \mathrm{~cm})$ of heparin-agarose. The heparin was linked to Biogel A 15 M (200-400 mesh; Bio-Rad Laboratories) as described previously (9) for linkage to Bio-Gel A $5 \mathrm{M}$. The protein S peak from the blue Sepharose was dialyzed into $0.05 \mathrm{M}$ imidazole $\mathrm{HCl}, 1 \mathrm{mM}$ benzamidine $\mathrm{HCl}, 1 \mathrm{mM} \mathrm{CaCl}, \mathrm{pH} 6.0$ before application to the heparin-agarose column previously equilibrated in the above buffer. The column was developed with a linear gradient $(30 \mathrm{ml} /$ reservoir) containing the equilibration buffer in the lead reservoir, and $0.05 \mathrm{M}$ imidazole $\mathrm{HCl}$, $1 \mathrm{mM}$ EDTA, $1 \mathrm{mM}$ benzamidine $\mathrm{HCl}, \mathrm{pH} 6.0$, in the trailing buffer. Protein $S$ activity was associated with the last protein peak to emerge from the column. This peak constituted $>80 \%$ of the applied protein. The protein $S$ prepared in this manner is shown in Fig. 1 .

Treatment of the purified protein $S$ with thrombin destroyed the ability to serve as a cofactor for activated protein $\mathrm{C}$ as previously reported by others (4) (Fig. 2). The loss of the activated protein $C$ cofactor activity correlated with the disappearance of the protein $\mathrm{S}$ as monitored on polyacrylamide gels (Fig. 3).

Protein $\mathrm{C}$ and activated protein $\mathrm{C}$ were prepared either by conventional chromatographic methods (7) or by chromatography on a murine IgG monoclonal antihuman protein $\mathrm{C}$ antibody. Briefly, this antibody is conformationally specific and requires $\mathrm{Ca}^{2+}$ for interaction with protein $\mathrm{C}$. Removal of $\mathrm{Ca}^{2+}$ results in elution of human protein $\mathrm{C}$ (unpublished data). Protein $\mathrm{C}$ and activated protein $\mathrm{C}$ prepared by either method functioned identically in the protein $\mathrm{S}$ functional assay.

Laurell rocket electrophoresis of protein $S$. Protein $S$ in human plasma circulates both as a free protein and as a complex with complement component C4-binding protein (C4bp) (10). The complex does not dissociate during conventional agarose gel electrophoresis (11). To estimate immunologic levels of protein S, conventional Laurell rocket electrophoresis was employed with $7 \mathrm{mM}$ EDTA, and with $2 \%$ polyethylene glycol 6,000 in the agar plates. Agarose used in the plates (1\% Seakem ME agarose, FMC Corp., Marine Colloids Div., Rockland, ME) was made up with Paragon B-2 buffer (Beckman Instruments Inc., Fullerton, CA). The same buffer with 7 mM EDTA added was employed for electrophoresis. Goat IgG directed against human proteins $\mathrm{S}$ and $\mathrm{C}$ was produced as previously described (7). Samples of $15 \mu \mathrm{l}$ were electrophoresed at $2 \mathrm{~mA} / \mathrm{cm}$ at $8^{\circ} \mathrm{C}$ for $18 \mathrm{~h}$. Under these conditions, free plasma protein $\mathrm{S}$ can easily be detected, and at least some protein $S$ is separated from the protein S-C4bp complex and immunoprecipitated (see results). Sheep antihuman C4bp was obtained from Accurate Chemical \& Scientific Corp., Westbury, NY. The 


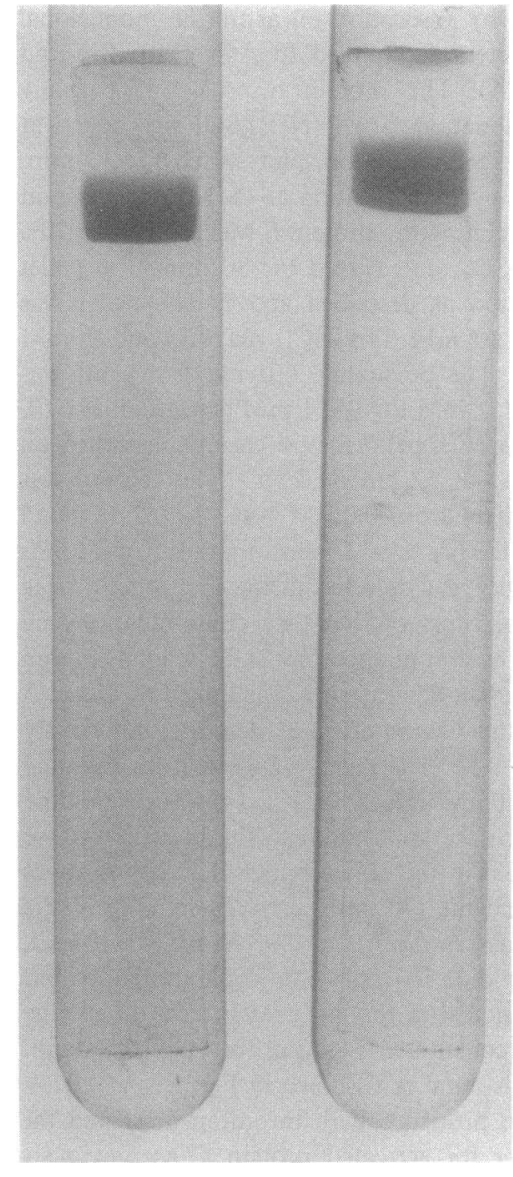

Figure 1. Purified human protein S. Samples of protein $\mathrm{S}$ were electrophoresed on $10 \%$ polyacrylamide gels containing sodium dodecyl sulfate. The sample on the left was denatured with sodium dodecyl sulfate before electrophoresis, and the sample on the right was reduced with beta-mercaptoethanol and denatured with sodium dodecyl sulfate before electrophoresis.

antibody did not cross-react with human protein $\mathrm{S}$ on Ouchterlony double diffusion over a wide range of antibody and antigen concentrations.

Protein S-deficient plasma. Goat IgG directed against human protein $\mathrm{S}$ was bound to Affigel 10 (Bio-Rad Laboratories) after dialysing

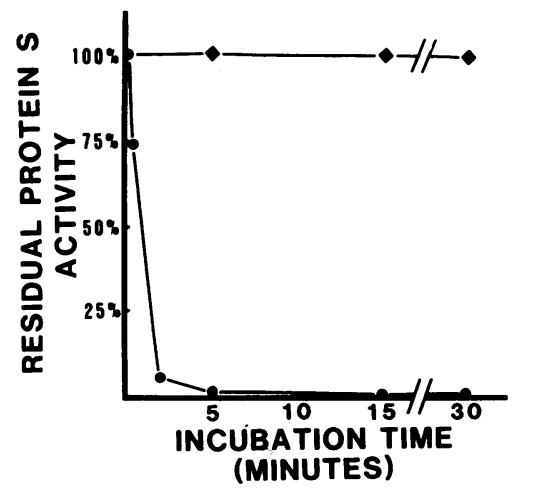

Figure 2. Loss of functional protein $\mathrm{S}$ activity after thrombin treatment. $50 \mu \mathrm{g}$ protein $\mathrm{S} /$ $\mathrm{ml}$ of Tris buffer, $\mathrm{pH}$ 7.4, containing $0.1 \mathrm{M}$ $\mathrm{NaCl}$ was treated with human thrombin at a final concentration of 5 $\mu \mathrm{g} / \mathrm{ml}(\bullet)$ or with buffer (४). The samples were incubated at $37^{\circ} \mathrm{C}$ and at times indicated, $50-\mu l$ aliquots were re-

moved and added to $50 \mu \mathrm{l}$ antithrombin III $(1.6 \mathrm{mg} / \mathrm{ml}$ concentration in Tris/saline buffer). After $\mathbf{3 0} \mathrm{min}$ incubation, the samples were assayed for residual protein $\mathrm{S}$ activity and expressed as a percentage of initial activity.

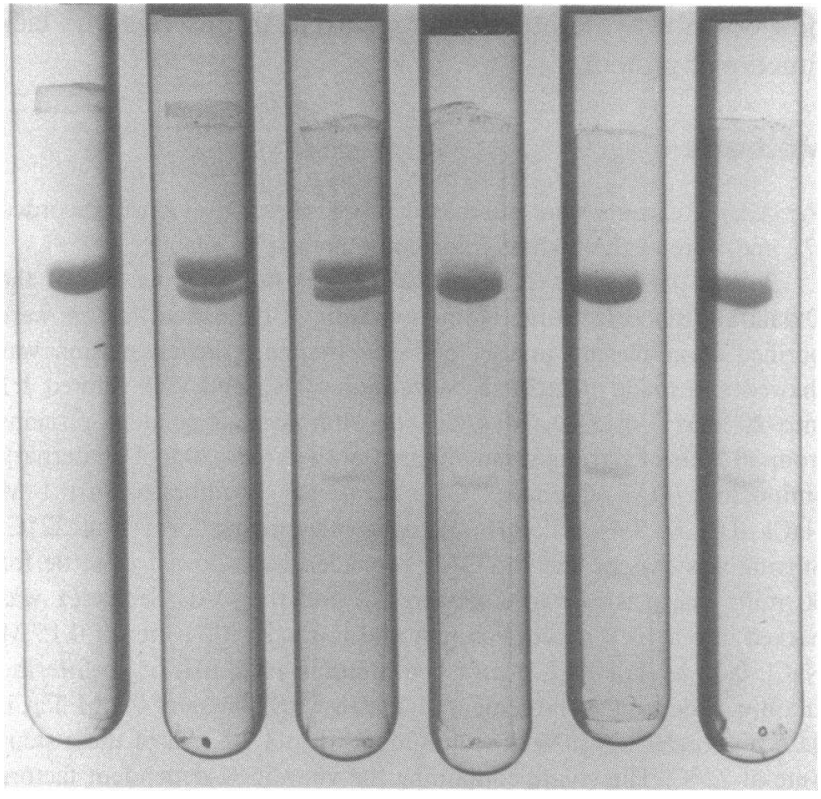

Figure 3. Time course of protein $\mathbf{S}$ degradation by thrombin. Protein $S$ was incubated with thrombin under conditions outlined in Fig. 2. At times indicated, aliquots were removed and denatured by addition of sodium dodecyl sulfate and beta-mercaptoethanol, and immediate immersion of the tubes containing the samples in a boiling waterbath. Samples were electrophoresed on $10 \%$ polyacrylamide gels. Gel 1, unreduced starting protein S; gel 2, reduced starting protein S; gels $3,4,5$, and 6 , reduced samples at $15 \mathrm{~s}, 2 \mathrm{~min}, 5 \mathrm{~min}$, and $30 \mathrm{~min}$. The band with relative mobility of $58 \%$ is thrombin. Protein $S$ incubated without thrombin showed no degradation.

the antibody against $0.1 \mathrm{M} 3-(\mathrm{N}$-morpholino)propanesulfonic acid, $\mathrm{pH}$ 7.5. The antibody was bound at $\sim 10 \mathrm{mg} / \mathrm{ml}$ gel. A $1.5 \times 10 \mathrm{~cm}$ goatantihuman protein $S$ column was prepared and washed extensively in $20 \mathrm{mM}$ Tris buffer, $\mathrm{pH} 7.4$, containing $0.1 \mathrm{M} \mathrm{NaCl}$. Over this column $35 \mathrm{ml}$ citrated normal human plasma was passed at $7 \mathrm{ml} / \mathrm{h}$. Fractions containing the plasma were then pooled. No protein $S$ could be detected in the pooled deficient plasma by rocket immunoelectrophoresis or by the functional assay. The protein S-deficient plasma contained normal levels of Factors $\mathrm{X}$ and V, assayed as previously described (12, 13), and normal levels of protein $C$, measured functionally and immunologically (7). The activated partial thromboplastin and prothrombin times were unchanged after immunoadsorption.

Functional protein $S$ assay. The assay is based on the ability of protein $S$ to serve as a cofactor of the anticoagulant effects of activated protein $\mathrm{C}$. The prolongation of the Factor $\mathrm{Xa}$ one-stage clotting time by the activated protein $C$ is dependent on the protein $S$ content of the test plasma. In contrast, protein $S$ does not influence this assay in the absence of activated protein C. Compared with one-stage clotting assays for other coagulation factors, relatively high concentrations of normal plasma are required to observe the protein $S$ effects. To avoid significant changes in the levels of clotting factors in this assay, the standard curve was prepared by diluting normal plasma into protein S-deficient plasma to give $0,12.5,25$, and $50 \%$ normal protein $\mathrm{S}$ levels. The assay was performed in the following manner: to $100 \mu \mathrm{l}$ of protein S-deficient plasma at $37^{\circ} \mathrm{C}$ was added $100 \mu \mathrm{l}$ cephalin (Sigma 
Chemical Co., St. Louis, MO), $100 \mu \mathrm{l}$ of $25 \mathrm{mM} \mathrm{CaCl}_{2}$, and $100 \mu \mathrm{l}$ of bovine Factor $\mathrm{Xa}$. The purified Factor $\mathrm{Xa}$ (14) was diluted into $0.1 \mathrm{M}$ $\mathrm{NaCl}, 0.02 \mathrm{M}$ Tris $\mathrm{HCl}, 1 \mathrm{mg} / \mathrm{ml} \mathrm{BSA}, \mathrm{pH} 7.5$ to give a 30-s clotting time in the above assay. The same clotting time $( \pm 1 \mathrm{~s})$ was obtained when the normal plasma dilutions were substituted for the protein S-deficient plasma. Thus, in the absence of activated protein $\mathrm{C}$, this coagulation assay is unaffected by protein $\mathrm{S}$. To prepare the standard curve, $10 \mu \mathrm{l}$ of activated protein $\mathrm{C}(5.6 \mu \mathrm{g} / \mathrm{ml})$ is added to either the protein S-deficient plasma or the normal plasma dilutions just before adding the other components of the clotting mixture. In the presence of activated protein $\mathrm{C}$, a linear relationship was obtained between the percent normal plasma and the prolongation of the clotting time (Fig. 4). The lower limit for detection of protein $S$ is $\sim 5 \%$. Purified protein $S$ and plasma dilutions exhibited the same dilution curve slope. Based on this assay the functional protein $\mathrm{S}$ content of normal plasma seems to be $\sim 8 \mu \mathrm{g} / \mathrm{ml}$, in good agreement with the $10 \mu \mathrm{g} / \mathrm{ml}$ of free protein S estimated immunologically by Dahlback (15). The standard deviation of the assay was $5.2 \%$, and standard error was $1.2 \%$. Preliminary data suggest that Russell's viper venom may be employed in the assay instead of Factor Xa.

Plasmas from patients on warfarin therapy or from patients with liver failure have increased sensitivity to the anticoagulant effects of activated protein $C$. The standard dilutional curves generated using these plasmas are not parallel to that made by mixing normal plasma with protein S-deficient plasma. This assay is, therefore, not appropriate for these patients.

Barium adsorption precipitation, elution, and chromatography of patient plasma. $8 \mathrm{ml}$ of $1 \mathrm{M}$ barium chloride was slowly added with constant stirring to $100 \mathrm{ml}$ of citrated patient plasma containing 1 $\mathrm{mM}$ benzamidine at $4^{\circ} \mathrm{C}$. The barium citrate precipitate was collected by centrifugation at $2,000 \mathrm{rpm}$ at $4^{\circ} \mathrm{C}$ for $10 \mathrm{~min}$. No protein $S$ could be detected immunologically in the supernatant. The surface of the precipitate was washed with $5 \mathrm{ml}$ of cold $20 \mathrm{mM}$ Tris buffer, $\mathrm{pH} 7.4$, containing $0.1 \mathrm{M} \mathrm{NaCl}$, and the precipitate was resuspended in $10 \mathrm{ml}$ $0.2 \mathrm{M}$ Tris buffer, $\mathrm{pH} 7.4$, containing $0.2 \mathrm{M}$ EDTA and $1 \mathrm{mM}$ benzamidine. When the precipitate had dissolved with gentle stirring, the barium eluate was desalted on a G-75 Sephadex column $(2.5 \times 50$ $\mathrm{cm}$ ), equilibrated, and developed with $5 \mathrm{mM}$ MES buffer, $\mathrm{pH} 6.0$, containing $0.2 \mathrm{M} \mathrm{NaCl}$. Fractions containing eluted proteins from this column were loaded on a $0.6 \times 40 \mathrm{~cm}$ QAE-Sephadex column equilibrated with $5 \mathrm{mM}$ MES buffer, $\mathrm{pH} 6.0$, containing $0.2 \mathrm{M} \mathrm{NaCl}$. The

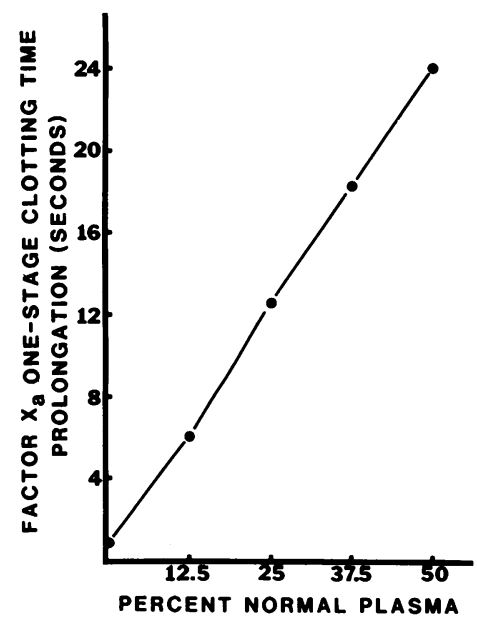

Figure 4. Standard curve for functional protein $\mathbf{S}$ assay. Increasing concentrations of pooled normal plasma were empooled to construct the standard curve. column was developed with a linear $0.2-0.5 \mathrm{M} \mathrm{NaCl}$ gradient with 50 $\mathrm{ml}$ in each gradient chamber. Normal plasma was processed in an identical manner as a control. Functional and immunologic protein $\mathrm{S}$ levels were assayed as described above. Neither eluate contained fractions that inhibited the functional assay.

Patients. The protein S-deficient proband (E.G.) is a 17-yr-old white male. At age 14 he was hospitalized for venographically documented left lower extremity deep vein thrombosis with clots in both calf and thigh. At age 15 the patient had an episode of multiple pulmonary emboli resulting from documented lower extremity deep vein thrombosis. At age 16 he again had documented deep vein thrombosis. All coagulation studies, including prothrombin time, partial thromboplastin time, antithrombin III (104\%), and protein C (110\% functional, $100 \%$ immunologic), were normal. The patient was studied when he had been off anticoagulants for 7 wk.

The proband's brother (W.G.) is $27 \mathrm{yr}$ old. He developed thrombophlebitis of the left leg following a motorcycle injury at age 15 . He again developed deep vein thrombosis of the right calf at $26 \mathrm{yr}$ of age. Both thrombosis episodes were documented venographically. The patient's coagulation profile, including partial thromboplastin time, antithrombin III $(90 \%)$, and protein C (87\% functional, $95 \%$ immunologic), is normal. The patient had been off warfarin and heparin for $45 \mathrm{~d}$ when he was studied.

The parents and two other siblings, ages 16 and $23 \mathrm{yr}$, have no history of thrombosis. The maternal grandmother had deep vein thrombosis at an advanced age. There is no consanguinity in the family.

Normal plasma samples for determining normal ranges and for making a normal pool were obtained from 20 healthy individuals, not on anticoagulant therapy, and with no personal or family history of thrombosis, ranging from 21 to $62 \mathrm{yr}$ of age.

\section{Results}

Normal plasma is anticoagulated by activated protein $\mathrm{C}$. The addition of activated protein $\mathrm{C}$ to the plasma of two brothers with severe recurrent venous thrombosis did not anticoagulate their plasma, as evidenced by no significant change in the clotting time after additional activated protein $\mathrm{C}$ (Table I).

Table I. Effects of Activated Protein C on Factor Xa One-stage Clotting Time

\begin{tabular}{llll}
\hline & Clotting time & & \\
\cline { 2 - 4 } & & $\begin{array}{l}\text { Plasma } \\
\text { + activated } \\
\text { protein C }\end{array}$ & $\begin{array}{l}\text { Plasma } \\
\text { + protein S } \\
\text { + activated } \\
\text { protein C }\end{array}$ \\
\hline & $(s)$ & $(s)$ & $(s)$ \\
Normal & $30.1 \pm 0.3$ & $55.0 \pm 2.0$ & $57.0 \pm 2.2$ \\
Patient (E.G.) & $29.2 \pm 0.3$ & $29.4 \pm 0.3$ & $47.7 \pm 1.7$ \\
Patient (W.G.) & $30.2 \pm 0.4$ & $30.1 \pm 0.4$ & $56.9 \pm 2.1$
\end{tabular}

Plasma was supplemented with activated protein $\mathrm{C}(0.56 \mu \mathrm{g} / \mathrm{ml} \mathrm{con-}$ centration in plasma) immediately before determination of the clotting time, as was protein $S$ (final concentration, $20 \mu \mathrm{g} / \mathrm{ml}$ in plasma). Three determinations were made on each sample. Addition of protein $\mathrm{S}$ alone did not significantly change the clotting times determined for the plasma samples without added activated protein $\mathrm{C}$. 
When the plasma of these two individuals was supplemented with purified protein $\mathrm{S}$, the addition of activated protein $\mathrm{C}$ resulted in anticoagulation. The addition of protein $S$ alone did not affect the clotting time.

To quantitate the functional protein $S$ activity present in the patients' plasma, we developed the functional protein $S$ assay described in Methods. Using this assay, we determined that normal individuals have protein $S$ activity between 160 and $68 \%$ with a mean of $100 \%$. We also determined that the brothers with recurrent thrombosis had no detectable protein $S$ activity (Fig. 5), whereas two other siblings and one grandparent had normal levels of protein $\mathrm{S}$. The mother and father had reduced levels of 30 and $15 \%$, respectively. Neither parent has had any thrombotic disease.

To determine if any immunologically functional levels of detectable protein $\mathrm{S}$ were present in the plasma of the deficient brothers, Laurell rocket electrophoresis was carried out. Analysis of the plasma of the brothers with thrombosis (Fig. 6) revealed levels of 18 and $13 \%$ for W.G. and E.G., respectively. Certain other family members had less immunoprecipitable protein $\mathrm{S}$ than normal plasma. These included the mother with $49 \%$, the father with $71 \%$, and an unaffected younger brother with $50 \%$. Protein $S$ is known to exist in plasma both free and complexed to complement component C4bp (8). Note that the immunoelectrophotic technique employed does not permit quantitation of the relative amount of free protein $S$ versus the amount of protein $S$ in the protein S-C4bp complex.

We wished to determine if any free, but functionally inactive, protein $S$ could be identified in the plasma of the functionally deficient individuals. To determine this, plasma from the brother with $18 \%$ immunologically detectable protein $\mathrm{S}$ was subjected to barium citrate adsorption and elution to concentrate the vitamin $\mathrm{K}$-dependent plasma proteins. The barium eluate was then subjected to ion exchange chromatography (Fig. 7). As has been seen by others (10), the barium eluate from normal plasma contained two distinct peaks of immunologically detectable protein $S$ : the first peak in the region of the protein S-C4bp complex, and the second peak in the region where free protein $S$ is eluted. Functional protein $S$ activity is associated with the second (free) protein $S$ peak. The barium eluate from the patient plasma contained only a single protein $S$ peak, eluting from the column in the region of the protein S-C4bp complex. No protein $S$ activity was present. The Laurell rockets of these two columns are shown

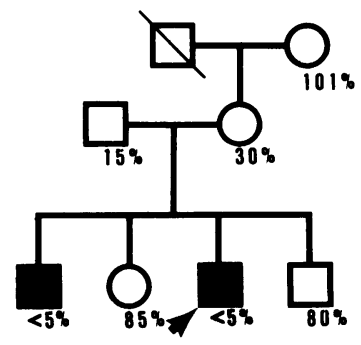

Figure 5. Family with recurrent thrombosis. The proband is indicated by the arrow. Functional protein $\mathbf{S}$ levels are shown for each family member. No protein $S$ activity could be detected in the two affected brothers at the lower limit of sensitivity of the assay.

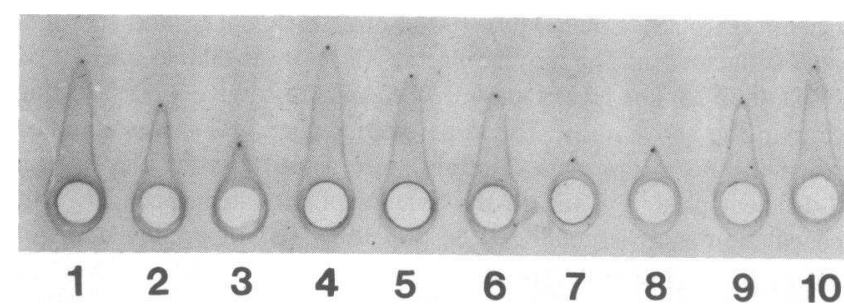

Figure 6. Laurell rocket electrophoretic analysis of a protein Sdeficient family. Wells $1-3,100,50$, and $25 \%$ pooled normal plasma; well 4, grandmother (104\%); well 5, father (71\%); well 6, mother (49\%); well 7, proband (13\%); well 8, protein S-deficient brother (19\%); wells 9 and 10, unaffected brother and sister.

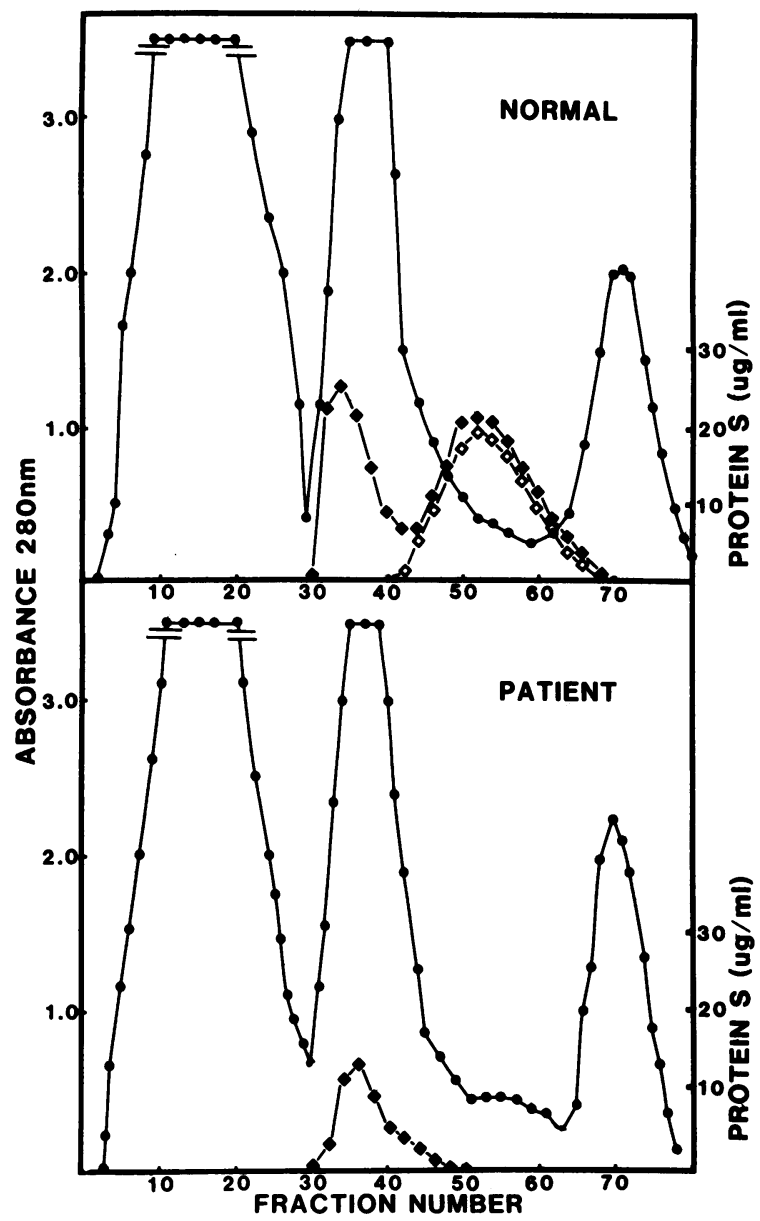

Figure 7. Ion exchange chromatography of barium eluate of protein S-deficient individuals and of normal plasma. Barium citrate adsorption and elution with subsequent desalting and chromatography over QAE-Sephadex are described in Methods. A 0.2 to $0.5 \mathrm{M} \mathrm{NaCl}$ gradient was initiated at fraction 20 . The absorption at $280 \mathrm{nM}(\bullet)$ is shown as is protein $S$ detected immunologically $(\bullet)$ by Laurell rocket electrophoresis and by the functional protein $\mathrm{S}$ assay $(\diamond)$. C4bp (detected by Ouchterlony double diffusion) was present in the major peak following the breakthrough (fractions $30-45$ ) as observed by others. 


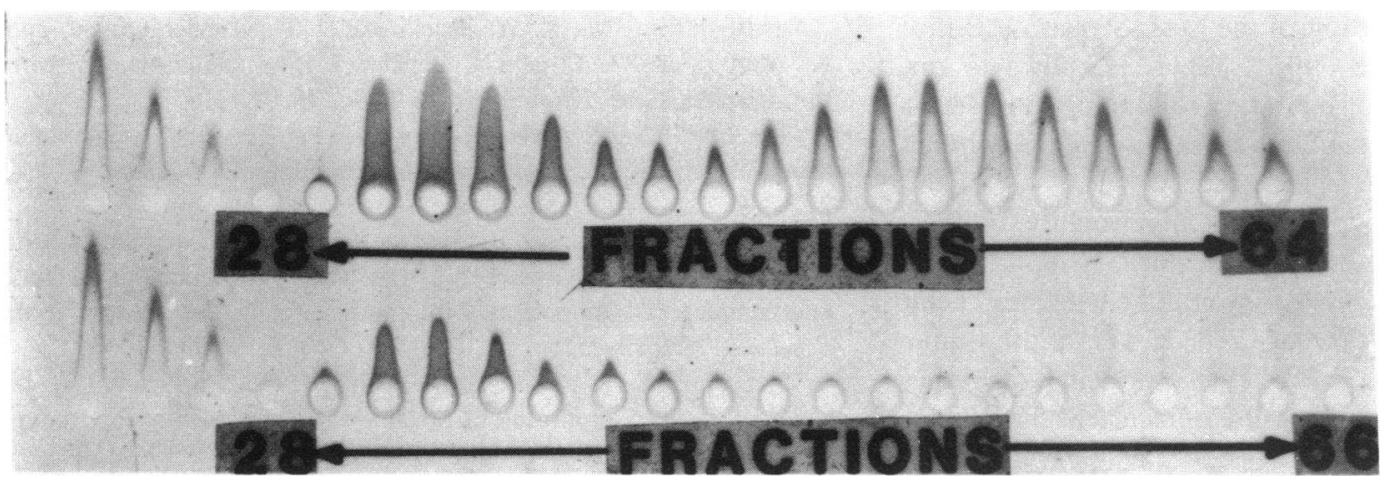

Figure 8. Rocket immunoelectrophoretic analysis of eluates of QAE-Sephadex columns shown in Fig. 7. Wells 1, 2, and 3 contained $30 \mu \mathrm{g} / \mathrm{ml}, 20$ $\mu \mathrm{g} / \mathrm{ml}$, and $10 \mu \mathrm{g} / \mathrm{ml} \mathrm{pu}-$ rified protein $\mathrm{S}$. Evennumbered column fractions were analysed as indicated across column eluates.

in Fig. 8. The rockets from the protein S-C4bp peak have immunoprecipitated material inside them, suggesting continuous separation of the C4bp complex during electrophoresis. The rockets in the region of the free protein $S$ give a sharp outline closely resembling that seen with purified protein $S$.

The previous demonstration that both brothers responded to addition of purified protein $\mathrm{S}$ suggested that their deficiency was not due to the presence of an inhibitor. To exclude the possible presence of a slow-acting inhibitor, normal plasma was combined in equal parts with plasma from each of the two brothers. The plasma mixtures were incubated at $37^{\circ} \mathrm{C}$, and remaining protein $\mathrm{S}$ activity was determined over a 2-h period (Fig. 9). No significant change in protein $S$ level was observed in normal plasma incubated with the plasma from either brother.

\section{Discussion}

The in vitro demonstration by Walker (2) that expression of bovine-activated protein $C$ anticoagulant activity requires protein $\mathrm{S}$ suggested to us that functional protein $\mathrm{S}$ deficiency, like protein $\mathrm{C}$ deficiency, might be manifested as an increased thrombotic tendency. These observations also suggested that protein $\mathrm{S}$ deficiency could be monitored in plasma as an inability to respond to activated protein C. A simple Factor $\mathrm{Xa}$ one-stage clotting assay done in the presence of activated

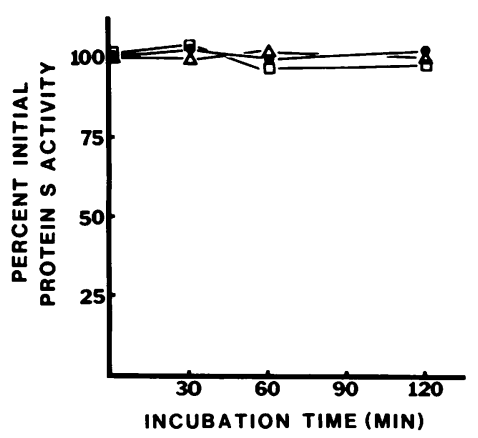

Figure 9. Effect on protein $S$ level in normal plasma of incubation with plasma from deficient patients. Plasma from the proband $(\Delta)$, proband's brother $(\square)$, and a normal individual (•) were each mixed in equal parts with pooled normal plasma and incubated at $37^{\circ} \mathrm{C}$. At the times indicated, functional protein $\mathrm{S}$ levels were determined. protein $\mathrm{C}$ allows for rapid screening of patients with potential protein S deficiency. Presumably, this assay would detect patients with functional protein S deficiency, patients lacking the protein $S$ antigen, or patients with circulating protein $S$ inhibitors.

The two brothers described here lack detectable functional protein $\mathrm{S}$, and have evidence of recurrent thrombotic disease. The biochemical basis of the functional protein $\mathrm{S}$ deficiency in these patients is not clear. Although the brothers do have protein $\mathrm{S}$ antigen based on the chromatographic studies presented here, all of the protein $S$ appears to be complexed to C4bp. Such binding has been described in normal plasma by Dahlback and Stenflo (8). This complex from either the patient plasma or from normal plasma does not support activated protein $\mathrm{C}$ anticoagulant activity. Why only the complex is observed in patient plasma is uncertain. Either the patients' protein $S$ could have an increased affinity for $C 4 b p$ or their C4bp could have increased affinity for protein $S$. The latter does not seem likely because the addition of patient plasma to normal plasma does not inhibit the functional protein $S$ activity of normal plasma.

Whatever the pathophysiologic abnormality, the inheritance pattern suggests that the total lack of functional protein $S$ activity may be a homozygous condition. The levels of 15 and $30 \%$ in the parents are consistent with heterozygous individuals, who would produce totally deficient children. Neither parent has had thromboembolic disease, suggesting that even signifcantly reduced protein $S$ levels may be sufficient to prevent thrombosis. This finding may be similar to protein $\mathrm{C}$ deficiency in which certain individuals with significantly reduced levels of protein $\mathrm{C}$ (presumably heterozygous for protein $\mathrm{C}$ deficiency) do not have a history of thrombosis (16).

The availability of a rapid, sensitive one-stage functional assay for protein $\mathrm{S}$ limits the necessity for immunological detection. This is fortunate since protein $\mathrm{S}$ seems to circulate in at least two forms; free, and complexed to C4bp (8). The presence of the complex complicates interpretation of electroimmunoassays. Under our immunoelectrophoresis conditions, at least some of the protein $\mathrm{S}$ in the complex is detected by immunoprecipitation, since clearly visible precipitation 
rockets develop in that portion of the QAE Sepharose elution profile where the protein S-C4bp complex is known to run. More exact measurement of the total immunologically detectable protein $S$ will require methods for separating the complex or detecting protein $\mathbf{S}$ while it is bound.

Because the only known clotting abnormality in these patients is a functional protein $S$ deficiency, it is likely that this deficiency causes the observed thrombotic tendency. These findings suggest that, like protein $C(5,6,17)$, antithrombin III (18), and plasminogen (19) deficiencies, protein S deficiency should be examined as a possible cause of recurrent thrombosis.

\section{Acknowledgments}

We thank Deborah Doray for her excellent technical assistance, as well as Gary Ferrell and Eric Wassilak for theirs. The help of Germaine Bohlman in obtaining patient samples is also greatly appreciated, as is the assistance of Dr. Jim Atkins. We would also like to thank Miss DeVonna Hill and Mrs. Barbara Irish for assistance in the manuscript preparation.

This research was supported by National Institutes of Health grants 1-R01-HL-30443, 1-R01-HL30340, and 5-R01-HL29807, and was performed during Dr. Edmund's tenure as an Established Investigator of the American Heart Association, with funds contributed in part by the Oklahoma Affiliate.

\section{References}

1. DiScipio, R. G., M. A. Hermodson, S. G. Yates, and E. W. Davie. 1977. A comparison of human prothrombin, factor IX, factor X, and protein S. Biochemistry. 16:698-706.

2. Walker, F. J. 1980. Regulation of activated protein C by a new protein. J. Biol. Chem. 255:5521-5524.

3. Walker, F. J. 1981. Regulation of activated protein C by protein $\mathrm{S}$, the role of phospholipid in factor Va inactivation. J. Biol. Chem. 256:11128-11131.

4. Suzuki, K., J. Nishioka, and S. Hashimoto. 1983. Regulation of activated protein $\mathrm{C}$ by thrombin modified protein S. J. Biochem. (Tokyo). 94:699-705.

5. Griffin, J. H., T. S. Zimmerman, A. J. Kleiss, and C. Wideman. 1981. Deficiency of protein $C$ in congenital thrombotic disease. $J$. Clin. Invest. 68:1370-1373.
6. Bertina, R. M., A. W. Broekmans, I. K. van der Linden, and K. Mertens. 1982. Protein C deficiency in a Dutch family with thrombotic disease. Thromb. Haemostasis. 48:1-5.

7. Comp, P. C., R. R. Nixon, and C. T. Esmon. 1984. A functional assay for protein $\mathrm{C}$ using thrombin-thrombomodulin. Blood. 63:1521.

8. Dahlbäck, B., and J. Stenflo. 1981. High molecular weight complex in human plasma between vitamin $\mathrm{K}$-dependent protein $\mathrm{S}$ and complement component $\mathrm{C} 4 \mathrm{~b}$-binding protein. Proc. Natl. Acad. Sci. USA. 78:2512-2516.

9. Esmon, C., G. Grant, and J. Suttie. 1975. Purification of an apparent rat liver prothrombin precursor: characterization and comparison to normal rat prothrombin. J. Biol. Chem. 14:1595-1600.

10. Dahlback, B. 1983. Purification of human C4-binding protein and formation of its complex with vitamin $\mathrm{K}$-dependent protein $\mathrm{S}$. Biochem. J. 209:847-856.

11. Dahlback, B., and B. Hildebrand. 1983. Degradation of human complement component $\mathrm{C} 4 \mathrm{~b}$ in the presence of the $\mathrm{C} 4 \mathrm{~b}$-binding protein. Biochem. J. 209:857-863.

12. Bachman, F., F. Duckert, and F. Koller. 1958. The Stuart Prower factor assay and its clinical significance. Thromb. Diath. Haemorrh. 2:24-34.

13. Esmon, C. T. 1979. The subunit structure of thrombinactivated factor V. J. Biol. Chem. 254:964-973.

14. Skogen, W. F., C. T. Esmon, and A. C. Cox. 1984. Comparison of coagulation factor $\mathrm{Xa}$ and Des (1-44) factor $\mathrm{Xa}$ in the assembly of prothrombinase. J. Biol. Chem. 259:2306-2310.

15. Dahlback, B. 1983. Purification of human vitamin K-dependent protein $S$ and its limited proteolysis by thrombin. Biochem. J. 209:837846.

16. Seligson, U., A. Berger, M. Abend, L. Rubin, D. Attias, A. Zivelin, and S. Rapaport. 1984. Homozygous protein C deficiency manifested by massive venous thrombosis in the newborn. $N$. Engl. J. Med. 310:559-562.

17. Branson, H. E., R. Marble, J. Katz, and J. H. Griffin. 1983. Inherited protein $\mathrm{C}$ deficiency and coumarin responsive chromic relapsing purpura fulminars in a newborn infant. Lancet. I:1165-1168.

18. Egeberg, O. 1965. Inherited antithrombin deficiency causing thrombophilia. Thromb. Diath. Haemorrh. 13:516-530.

19. Aoki, N., M. Moroi, Y. Sakata, N. Yoshida, and M. Matsuda. 1978. Abnormal plasminogen. A heriditary molecular abnormality found in a patient with recurrent thrombosis. J. Clin. Invest. 61:11861195. 